Pieter Dhondt

\title{
Searching for a (New) Self-legitimation? How Three Belgian (State) Universities Celebrated Their Bicentenary in 2017
}

\begin{abstract}
In 2017, three universities in Belgium that had been established in 1817 by King William I of the United Kingdom of the Netherlands (in Ghent, Liège and Leuven), commemorated their bicentennial. The still existing Ghent University and University of Liège did so in a grandiose way. In Leuven, however, the celebration was limited to a modest workshop and its accompanying publication. By analysing the festivities at Ghent University in 2017 in a detailed way this contribution shows how the traditional elements of a university jubilee celebration gradually received a different interpretation. This introductory case study illustrates the aim of this contribution as a whole, namely to examine and discuss how the staging of university jubilees has changed under the pressure of social changes, how this was reflected in the use of 'celebratory mediality', and how these different acts of performing the jubilee interacted with a process of self-legitimation. By reviewing the diverse output realised as part of these different celebrations (in Ghent, Liège and to a lesser extent Leuven), the chapter proves how these anniversaries have been used as an opportunity to respond to current challenges that the university is facing as an institution. The two central messages of both celebrating universities - Ghent and Liège - are reflected in most, if not all, of the initiatives that were unfolded on the occasion of the festivities: defending and protecting the university by emphasising its possible social relevance, and creating a larger (university) community by investing into the natural partnership between city and university.
\end{abstract}

\section{Introduction}

Researching and writing its history has always been one of the tasks of the university. From the late Middle Ages, rectors and ordinary professors have delivered speeches on the occasion of anniversary celebrations in which they presented the glorious past of their own institution. Even so, the number of jubilee celebrations increased spectacularly in the second half of the nineteenth centu- 
ry. ${ }^{1}$ Generally, this kind of celebrations consisted of four elements. ${ }^{2}$ The central part was the academic ceremony where representatives from the political, religious and cultural elite were welcomed, where delegations from universities and scientific institutions from home and abroad delivered their often artfully presented congratulation addresses, and where honorary doctoral degrees were granted to distinguished members of the international scientific community. At most universities, the authorities seized the opportunity to reinforce relationships with their students, and with their city and its population. This resulted on the one hand in typical student activities such as a torchlight procession and drinking events, and on the other hand in events that were open to the general public, like a garden party, sporting occasions or an historic procession. Finally, the standard jubilee programme included the unveiling of statues, students' concerts, visits to the opera or other cultural activities.

Even though the character of the official anniversary ceremony shows a remarkable degree of continuity during the past one and a half century, nevertheless important gradual shifts with regard to the origin of the invitees can be noticed. The pursuit of a European orientation around the turn of the nineteenth to the twentieth century gave way in the interwar period to a return to a more national orientation. ${ }^{3}$ After the Second World War, again more attention was paid to the international perspective, which has certainly not completely disappeared today, but is clearly overshadowed by a focus on the local elite.

This stronger emphasis on the universities' local embedding during the last two or three decades seems somewhat contradictory in a globalised world. However, at least two arguments can help to explain this paradox. Firstly, universities are increasingly profiling themselves as each other's competitors (both nationally and internationally), what makes it naturally less obvious to honour each other with a birthday visit. Secondly, the university as an institution feels threatened in its existence and increasingly experiences the need to defend itself. The enduring commodification of academic research, in combination with attacks on

1 Dhondt, Pieter: Nineteenth-century university jubilees as the driving force of increasing Nordic cooperation. In: National, Nordic or European? Nineteenth-Century University Jubilees and Nordic Cooperation. Ed. by Pieter Dhondt. Leiden/Boston 2011 (Scientific and Learned Cultures and Their Institutions 25,4). pp. 1-9, p. 2.

2 Becker, Thomas P.: Jubiläen als Orte universitärer Selbstdarstellung. Entwicklungslinien des Universitätsjubiläums von der Reformationszeit bis zur Weimarer Republik. In: Universität im öffentlichen Raum. Ed. by Rainer Christoph Schwinges. Basel 2008 (Veröffentlichungen der Gesellschaft für Universitäts- und Wissenschaftsgeschichte 10). pp. 92-93.

3 Dhondt, Pieter: Nineteenth-century university jubilees as (rheotrical) attempts at increasing Nordic cooperation. In: Dhondt, National (cf. note 1), pp. 313-318. 
academic freedom - itself being one of the core characteristics of the university's identity - make the continued existence of the university no longer self-evident. ${ }^{4}$ One way of fending this menace off is by displaying its social relevance and possible social impact. ${ }^{5}$ In order to convey this message in a comprehensible and convincing way to the public (and to possible funders), it is much easier during such anniversary 'ceremonies' to 'show off' with concrete examples from the local and regional environment instead of aiming to demonstrate the, often more abstract, international relevance of the research realised by the celebrated university and her scholars.

This approach was clearly applied during the festivities at Ghent University in 2017 on the occasion of its bicentenary, as is shown in the analysis of these celebrations in the first section of this contribution. This introductory case study serves to illustrate the aim of this contribution as a whole, namely to examine and discuss how the staging of university jubilees has changed under the pressure of social changes, how this was reflected in the use of 'celebratory mediality', and how these different acts of performing the jubilee interacted with a process of self-legitimation. In the same year 2017, the two other universities in Belgium that had been established in 1817 by King William I of the United Kingdom of the Netherlands in Liège and Leuven, commemorated their bicentennial. By reviewing the diverse output realised as part of these different celebrations, the chapter proves how these anniversaries have been used as an opportunity to respond to the aforementioned current challenges. The second section focuses primarily on the official jubilee publications in Ghent and Liège, yet also pays attention to a book which commemorated the state university of Leuven. The third and final section deals with $21^{\text {st }}$-century medialities and assesses the attempts to interact with the larger public.

4 Literature is abundant with regard to this topic. Recent perspectives are offered by, among many others, Radder, Hans: From commodification to the common good: reconstructing science, technology, and society. Pittsburgh 2019 and Reichman, Henry: The future of academic freedom. Baltimore 2019.

5 See for instance Hoffman, Andrew J.: Academia's Emerging Crisis of Relevance and the Consequent Role of the Engaged Scholar. In: Journal of Change Management 16:2 (2016). pp. 77-96 and Gamoran, Adam: The Future of Higher Education Is Social Impact. https://ssir.org/articles/ entry/the_future_of_higher_education_is_social_impact (18.5.2018). 


\section{Festivities in Ghent: The Social Relevance of the University at Stake}

At the festive Sunday morning book presentation on the $8^{\text {th }}$ of October 2017 which kicked off 'Everyone UGent!', a free one-day city festival that served as the highlight of the bicentenary celebrations at Ghent University - the organisers strived for a middle way between emphasising the university's local and international relevance. The university jubilee publication that was presented then is titled Uit de ivoren toren. 200 jaar Universiteit Gent [Out of the ivory tower. 200 years Ghent University] and, in its own words, "shows how great the social involvement of scholars has always been and is". ${ }^{6}$ The Sunday matinee served as the perfect moment to highlight this message to a larger public. Three thematic pillars were selected, each of them elaborated through a short historical introduction, followed by a current interpretation of the theme and a debate about it; and each of them interpreting a broad and topical social and/or educational question through a concrete, local perspective. One of the themes discussed was the societal resistance in Europe against genetically modified organisms. The aim to present some concrete results from the research centre on microbiology, founded already in the 1870s, was tackled by starting from a regionally (and even nationally) well-known and highly mediatised 'field liberation' action. This protest action had taken place in 2011 in the nearby commune of Wetteren. On a trial field that was coordinated by a consortium of research institutes, including the university's research centre, activists had swapped the genetically modified potatoes with organic varieties. ${ }^{7}$ By referring to this controversy, the (local) public easily could identify with the topic under discussion.

On the same $8^{\text {th }}$ of October 2017, more than 230 activities were organised at more than twenty locations spread out over the city of Ghent: street performances, children's workshops, interactive demonstrations, experiments, concerts, science shows, short lectures, guided tours, exhibitions, a book market, amongst else. The tentative list indicates how the third and fourth element of the traditional jubilee celebrations were now combined into a varied offer of all kinds of cultural events and activities intended for the general public, primarily com-

6 Uit de Ivoren Toren. 200 jaar Universiteit Gent. Boekvoorstelling 8 oktober in Vooruit. https:// mailchi.mp/a6228ec60fe4/uit-de-ivoren-toren-uitnodiging-boekvoorstelling-8-oktober?e= 6fcc4576d1 (8.10.2017).

7 See Maeseele, Pieter et al.: In Flanders Fields: De/politicization and Democratic Debate on a GM Potato Field Trial Controversy in News Media. In: Environmental Communication 11:2 (2017). pp. $166-183$. 
ing from Ghent. In many cases, the link with the history of the university was fairly difficult to find. The university's birthday was simply used as an excuse to organise a big folk festival.

The list of organisers of these activities was as diverse as the list of the events itself, going from professional festival organisers, over the university's own jubilee committee and public relations department, to faculties, research institutes, departments, professors and, obviously, students. However, one of the most visible shifts in the current implementation of the four elements of the typical jubilee celebration, as it took shape from the nineteenth century, is the lack of proper student activities. Of course, students are still involved in today's jubilees in many different ways, but they no longer use them as an opportunity to profile themselves as a separate group. As the author of this contribution has observed elsewhere, from the early modern period onwards, universities gradually became more established institutions, increasingly integrated into the territorial state. In result of that, students became alienated from their masters (professors) and developed a separate corporate identity, different from the university as a whole. They began to manifest this on the occasion of university jubilees by organising their own and typical student activities. Even in recent years, students feel encouraged to utter criticism towards current practices in society and towards state institutions, such as universities, and thus express the fight for common ideals and adherence to a different identity, yet now as belonging to a separate age group, rather than as being a constituent part of the celebrating 'uni'versity. ${ }^{8}$

In line with this development, students from Ghent University did not play any prominent role in the bicentenary celebrations, but still enthusiastically joined the 'Everyone UGent' city festival, also by organising events themselves, consistent with the general message of the commemoration and the university's jubilee publication: Out of the Ivory Tower. ${ }^{9}$ This leitmotif nicely illustrates how also today anniversaries are still used as an opportunity to respond to a particular crisis and/or to current trends, ${ }^{10}$ in this case being, firstly, the (perceived)

8 Dhondt, Pieter and Laura Kolbe: Student Identity and Radicalism. In: Student Revolt, City, and Society in Europe. From the Middle Ages to the Present. Ed. by Pieter Dhondt and Elizabethanne Boran. New York 2018 (Routledge Studies in Cultural History 52). pp. 115-119, p. 119. 9 Deneckere, Gita: Uit de ivoren toren. 200 jaar Universiteit Gent. Gent 2017.

10 See for instance Gerber, Stefan et al.: Einleitung. In: Traditionen - Brüche - Wandlungen. Die Universität Jena 1850 - 1995. Ed. by Senatskommission zur Aufarbeitung der Jenaer Universitätsgeschichte im 20. Jahrhundert. Köln 2009. pp. 1-22, p. 4; this theme is elaborated extensively in: University Jubilees and University History Writing. A Challenging Relationship. Ed. by Pieter Dhondt. Leiden/Boston 2015 (Scientific and Learned Cultures and Their Institutions 13). 
need to defend the university by paying more attention to its possible social impact and relevance, and, secondly, the willingness to take care of good relationships between the university, its city and the surrounding region. In this way, the Ghent jubilee functions as another example of how, by looking into its own history, the university as an institution led by traditions frequently has tried to provide itself with "expertise concerning its future organisation in a period of change". ${ }^{11}$ At the same time, this kind of master narrative for the volume as a whole successfully keeps the reader enthralled.

Immediately in the first chapter of Out of the Ivory Tower, which provides a broad overview of the university's two hundred years history, Gita Deneckere points to the original motto of the University of Ghent Inter utrumque, meaning 'between the two': "between the pursuit of wisdom through the practice of science and the service to prince and country". ${ }^{12}$ Obviously, this common thread is not equally visible in all the book's thematic chapters, yet both the selection of the themes and the way in which many of them are elaborated have at least partly been decided by it. For instance, the chapter on 'Industry and valorisation' reveals how the university throughout its history strived to be an "enterprising university paying attention to the social and economic application of its research results". ${ }^{13}$ Another chapter emphasises how several generations of professors at the medical faculty have taken up an exceptional degree of social involvement and commitment, resulting in a strong position of disciplines such as social medicine and psychiatry. And in the final chapter the worldwide leading role of the university in the fields of environmental technology and genetic engineering is dealt with and linked to the highly topical environmental issue.

11 Bruch, Rüdiger vom: Methoden und Schwerpunkte der neueren Universitätsgeschichtsforschung. In: Die Universität Greifswald und die deutsche Hochschullandschaft im 19. und 20. Jahrhundert. Ed. by Werner Bucholz. Stuttgart 2004 (Pallas Athene. Beiträge zur Universitäts- und Wissenschaftsgeschichte 10). pp. 9-26, p. 11. All translations of quotations have been made by the author.

12 Deneckere, Uit de ivoren toren (cf. note 9), p. 11.

13 Deneckere, Uit de ivoren toren (cf. note 9), p. 95. 


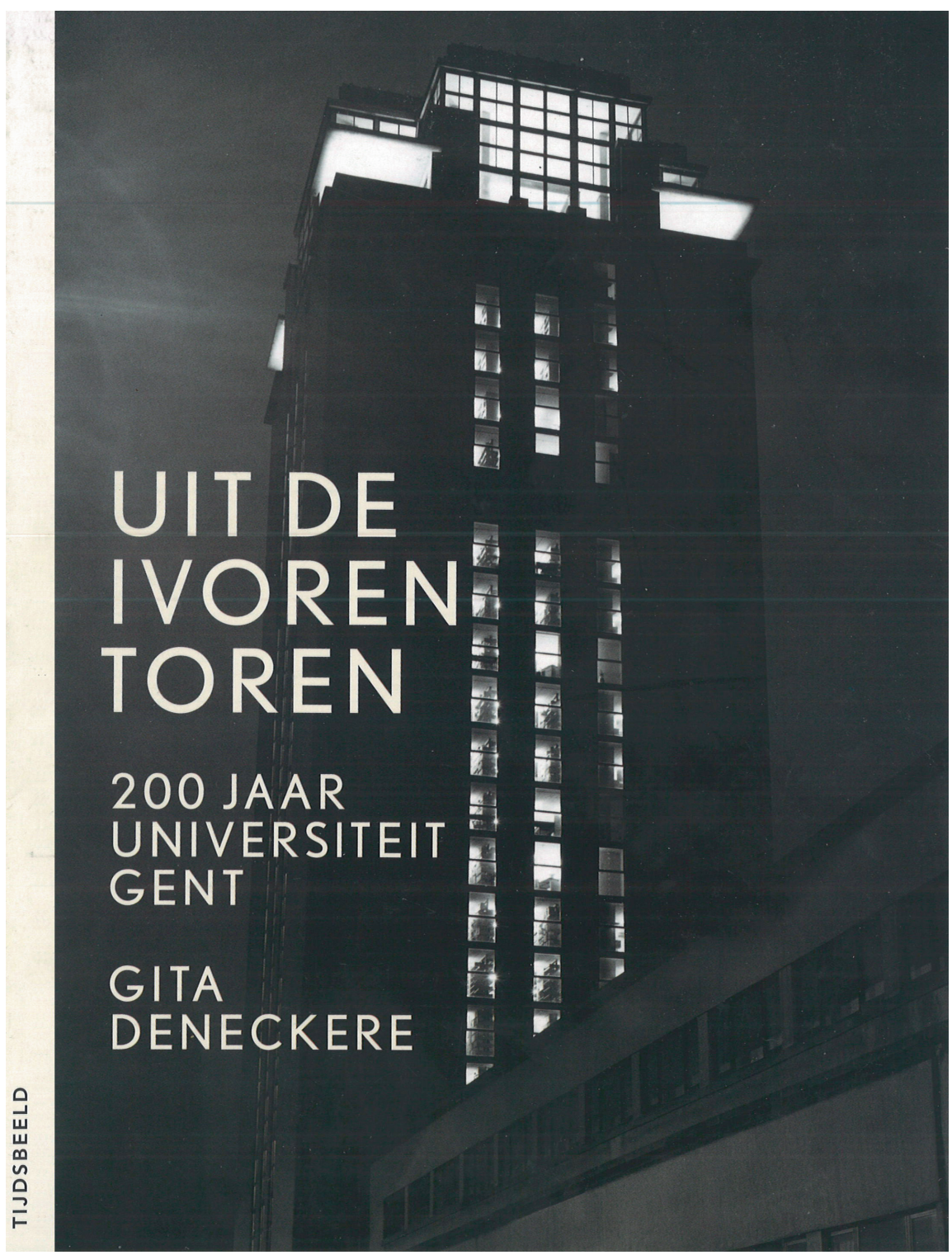

Abb. 11: The title of the jubilee publication is nicely in line with the message of the bicentenary of Ghent University as a whole: Looking back into the university's history serves to prove the social relevance of the university today. 


\section{The Official Jubilee Publications of Ghent, Liège (and Leuven): Service to the Society and/or to the City}

One important weakness concerning the research focus in Ghent on biotechnology was the lack of expertise at the university until the end of the 1990s to protect intellectual property in the form of patents, particularly in comparison to the KULeuven. The competition between the universities of Ghent and Leuven has a long-term historical background, having its origin to a large extent in their different inception. The old, medieval university in Leuven was abolished during the French revolutionary period, and only in 1817, when the Southern Netherlands (present-day Belgium) were part of the United Kingdom of the Netherlands, three state universities came in its place, in Ghent, Liège and Leuven. The latter one, at its turn, was abolished in 1835 in consequence of the coming into existence of two free universities during the year before: a Catholic University (that was founded in the small town of Malines, but moved to Leuven after the abolishment of the pre-existing state university), and its liberal counterpart, the free-thinking University of Brussels. From their foundation and actually even up to today, these ideologically opposed free universities did not only compete with each other, but also stood in large contrast to the state universities of Ghent and Liège. Since the state universities became autonomous in 1991, there is actually no longer a legal difference between free and state universities, but it has been a very conflict-ridden process to come this far, and the previously existing tensions definitely have not yet disappeared completely.

The last major conflict in this regard happened in the context of the socalled law on university expansion (1965), which determined the establishment of numerous new universities (free as well as state institutions, and the division of previously exclusively French-speaking institutions into separate Dutch and French-speaking ones). In a European perspective, this provincialisation of the university landscape in Belgium was much less unique than Deneckere suggests. ${ }^{14}$ More interesting, however, is how she indeed confirms the criticism at the time, namely that the government sacrificed the state universities to the proliferation of the free universities as a result of this fragmentation. But Deneckere does so in a much more subtle and neutral way than her colleagues from the for-

14 See, for instance, Dhondt, Pieter and Arto Nevala: The typical dilemma between university expansion and rationalization: Belgium (and Finland) since the 1960s. In: Kasvatus \& Aika, kasvatuksen historiallis-yhteiskunnallinen julkaisu 9:3 (2015). pp. 21-36. 
mer state University of Liège in their bicentenary jubilee publication of 2017. In this publication, Philippe Raxhon and Veronica Granata compare the financial impact of the 1965 university expansion law on the state universities' budget with "the thrill of the ice scalpel cutting through the steel of the Titanic's hull". ${ }^{15}$ This formulation seems to echo much of the earlier frustration about the relative loss of the state universities' former privileged status. To a certain extent, the authors prove how difficult it can be to maintain enough distance when writing the history of one's own institution, as occurs so often in the tradition of jubilee history writing. ${ }^{16}$

As a result of the ongoing communitarisation, ${ }^{17}$ the common and futile protest of the universities of Ghent and Liège against this law was actually the end of their common history. Unfortunately, but not really surprisingly, this common history receives very little attention in both the Ghent and the Liège jubilee publications. Merely with regard to the foundation period between 1817 and 1830, when the Southern Netherlands were part of the United Kingdom of the Netherlands, do the publications pay some attention to the communalities between the three state universities. Both Deneckere and Raxhon and Granata bring forward, for instance, the stipulation from the 1816 regulations which ordered the city administrations to provide buildings for the universities, yet they give quite a different interpretation to it. On the one hand, Deneckere uses it as an opportunity to include one of the book's many quips, here referring to the general prejudice about the stingy Dutchman: "The Dutchman would not be the Dutchman if he did not calculate. And so it happened."18

For Raxhon and Granata, on the other hand, this specific clause allows them to emphasise the long-term partnership between 'town and gown' in Liège, which goes back to the university's foundation period. This tight link functions as (one of) the guiding and convincing master narrative(s) of their volume, even if they mistakenly claim that the advisory commission to William I recommended the creation of three state universities, whereas in reality the commission members were highly in favour of only one university, in Leuven or Brussels. This

15 "[Le] frisson du scalpel de glace entamant comme une caresse la découpe de l'acier de la coque du Titanic"; Raxhon, Philippe in collaboration with Veronica Granata: Université de Liège (1817-2017): Mémoire et prospective. Liège 2017. p. 143.

16 For instance Müller, Winfried: Erinnern an die Gründung. Universitätsjubiläen, Universitätsgeschichte und die Entstehung der Jubiläumskultur in der Frühen Neuzeit. In: Berichte zur Wissenschaftsgeschichte 21 (1998). pp. 79-102, p. 94.

17 In a Belgian context, communitarisation means the transfer of powers from the central administration to the Flemish, French and German-speaking communities.

18 Deneckere, Uit de ivoren toren (cf. note 9), p. 14. 
lapsus at least suggests a much larger degree of support for the King's educational policy in the Southern Netherlands than actually existed. It is true that William I attempted to boost the upcoming industrial revolution and that in this regard "the Liège metropolis" was in fact "predisposed to benefit from the good graces of the sovereign". ${ }^{19}$ Yet it was far from evident up to just a few months before the final decision on the future Liège university that this could happen through the cooperation between industry and university, which is solemnised in Raxhon's and Granata's portrayal.

At the same time, the authors prove in a very convincing way how the university, the industrial sector and its surrounding city and region have taken profit from the synergy as it developed in the context of different waves of industrialisation and regional economic challenges up to the late $20^{\text {th }}$ century. In 1989 , for instance, the university service Interface was established in order to enable the implementation of specific expertise of academics in the business world. Its original idea was "first of all to focus on difficulties encountered by businesses in the region". ${ }^{20}$ In testimony of the successful cooperation between town and gown, a group of historians from the University of Liège also published a new history of the city on the occasion of the university's bicentenary. ${ }^{21}$ The increased attention was advantageous to both city and university in view of their public relations during the jubilee year.

A crucial challenge that the jubilee researchers and authors from Liège had to tackle when building up their core argumentation on the university-city-industry trierarchy concerns the selection of disciplines and examples. Several other university history committees have opted for a more fragmented kind of publication per faculty or per discipline and thought it a well-considered approach in the current climate of multiversity. ${ }^{22}$ And indeed is the integrated approach that Raxhon and Granata are striving for at times stretched to its limits. While there is no doubt about the expertise developed in Liège - also thanks to the university - in key industrial sectors such as electricity, chemistry and pharmacy in the 1880s, what kind of industrial strength holders emerged at the university and in regional technology during the twentieth century is unfortunately much less clear, apart from astrophysics being one of them. The rather ephemeral listing

19 Raxhon, Université de Liège (cf. note 15), p. 28.

20 Raxhon, Université de Liège (cf. note 15), p. 168.

21 Demoulin, Bruno (ed.): Histoire de Liège. Une cité, une capitale, une métropole. Liège 2017. 22 Dhondt, Pieter: University History Writing: More than a History of Jubilees? In: Dhondt, University Jubilees (cf. note 10). pp. 1-20, p. 12. 


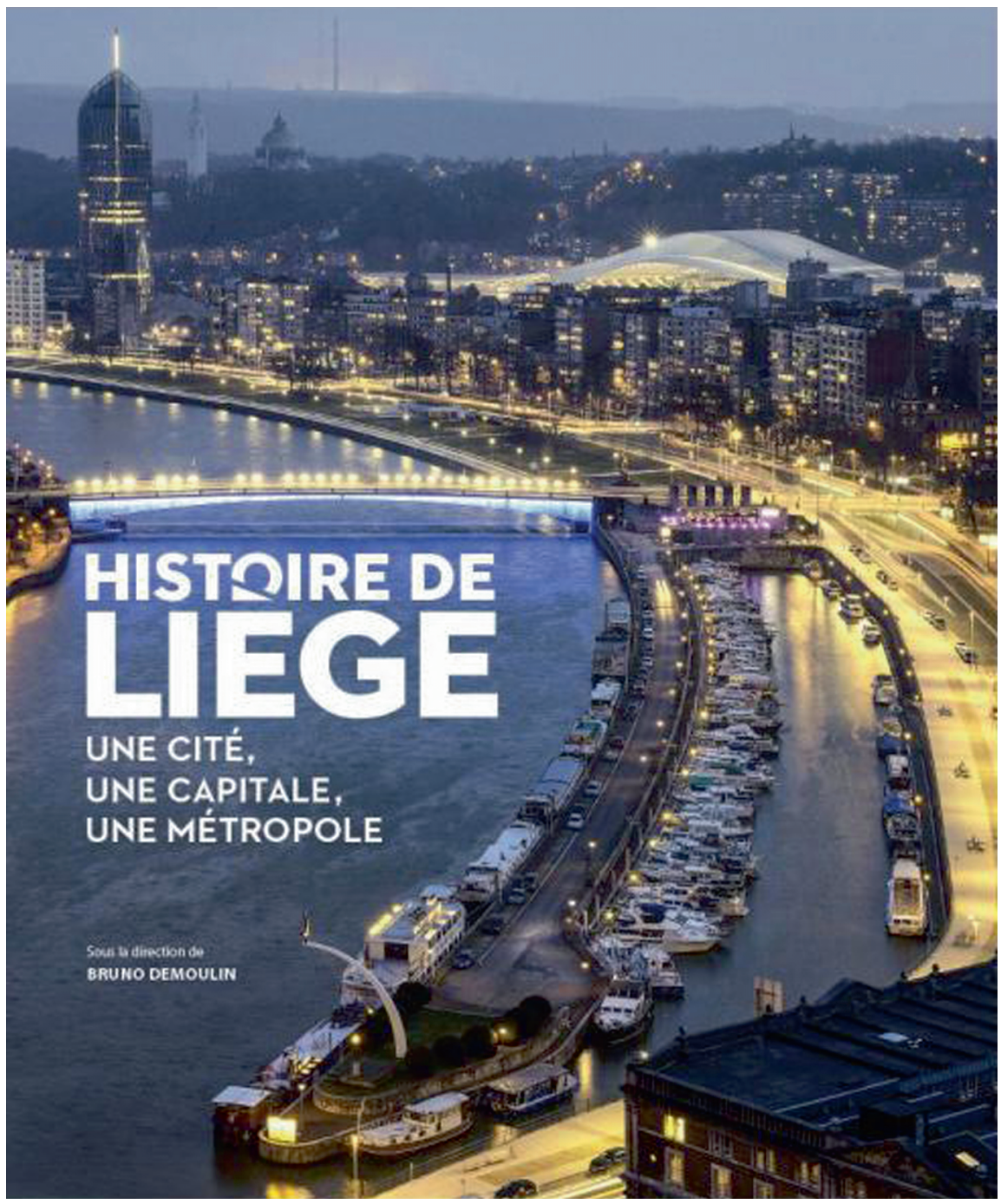

Abb. 12: The simultaneous publication of the university's two hundred years history and a new historical overview of the city of Liège confirms the message of a smooth cooperation between 'town and gown'.

of research institutes, different degrees and research figures "that speak for themselves" risks to be at the fringe of promo-talk. ${ }^{23}$

23 Raxhon, Université de Liège (cf. note 15), pp. 15-18. 
Even though the Ghent jubilee publication equally aims for an integrated approach, here the inevitable selection of disciplines results in a more balanced entity, as it is motivated by the willingness to focus on those subjects that were exceptionally well-developed at Ghent University and that enable to enforce the general argumentation of the aforementioned social involvement of Ghent scholars. However, two closely related problems occur in this regard. Firstly, there is the question whether the chosen story line has not determined the selection too much. ${ }^{24}$ To make it more concrete: was there indeed a specifically strong tradition of international law among Ghent law professors that qualified and still qualifies them to engage in international peace projects and human rights issues? ${ }^{25}$ Or is this claim mainly used to argue for the relevance of the chapter on 'War and peace'? Actually, such a dilemma could only have been addressed, secondly, by comparing the situation in Ghent with the one at other universities at home and abroad. Unfortunately, it is left up to the reader to assess the comparative degree of collaboration and resistance during the World Wars, or which role Ghent University played in the colonial adventure of the Belgian state (for instance, by offering a training in colonial agriculture from 1919 or by establishing of a medical campus from 1956, the so-called Ganda-Congo project).

All chapters close with a polemic question or a point of contention for the future, also the one dealing with 'Colonialism and development cooperation'. Here Deneckere criticises the lack of vision and the growing mutual competition regarding inter-university cooperation with the global South. By structuring her book like this, she deliberately contributes to the slogan of the festive year: 'A history full of a future'. Or, as she puts it herself: "The fact that the two Belgian state universities were founded precisely in the time of Wilhelm von Humboldt makes it all the more interesting to use the celebration for a look back with a view to the future."26 In Deneckere's narrative, the Humboldtian Bildungsideal is opposed to the predominant profitability thinking, in which individual self-development and the development of critical citizenship are at risk of being sacri-

24 On this kind of challenges, see for instance Paul, Herman: Key issues in historical theory. London 2015. pp. 56-69.

25 For instance, the establishment of the Institute of International Law in 1873, that received the Nobel Peace Prize in 1904, the engagement of Ghent professors at the Paris Peace Conference after the First World War and at the International Court of Justice in The Hague during the interwar period.

26 Genin, Vincent and Michael Auwers: 200 jaar universiteiten van Gent en Luik. Interview met Gita Deneckere en Philippe Raxhon. In: Contemporanea 39:3 (2017). https://www.con temporanea.be/nl/article/2017-3-aan-het-woord-200-jaar-ugent-en-ulg (26.2.2021). 
ficed..$^{27}$ Even though many readers can easily identify with her worries about the increasing commodification of the university, Humboldt and the ideals attributed to the so-called German model are referred to in an over-simplified way. ${ }^{28}$

Faithful to the Liège jubilee publication's subtitle Mémoire et prospective [Memory and prospective], the authors adopt a similar forward-looking perspective. Again, the reflection on the university's past is intended to give inspiration for the place and function of the university tomorrow. The perception that the contemporary university is threatened in its existence is countered by introducing the notion of "citizenship, the third beacon of university identity, in addition to teaching and research". ${ }^{29}$ The authors also recall the speech of Liège's rector Albert Corhay on the occasion of the opening of the academic year in September 2016 where Corhay presented his so-called 'charter of values' and evoked the "necessity: never to break the link with the city and its challenges". ${ }^{30}$ It is quite remarkable indeed, that the common third task of the university, service to society, in Liège is almost explicitly restricted to service to the city. The university is no longer an ivory tower, it is said here, yet a sentinel, protecting us against fake news and any kind of dogmatic thinking.

Just as topical, both in Ghent and Liège is the way in which the occasion of the bicentenary has been used to bring up another tricky point, namely the underrepresentation of women at the contemporary university. Even though at the end of the nineteenth century Belgian universities, except for the Catholic stronghold of Leuven, were less behind worldwide in terms of women's admission than Deneckere suggests, when jumping to today, it is definitely true that it remains extremely difficult for female researchers to break through the glass ceiling. Therefore, Deneckere plainly supports the plea of Anne De Paepe, the first female rector of her university (in 2013), for the introduction of quotas "as a temporary and necessary evil to change the old system from within". ${ }^{31}$ Concerning Liège, a similar kind of message is elaborated in a separate book, albeit in a slightly more subtle way. ${ }^{32}$ In this case the subject is broadened to the issue of gender studies. Through an extensive number of personal stories from (former)

27 See Nussbaum, Martha C.: Not for profit. Why democracy needs the humanities. Princeton 2016.

28 For instance Paletschek, Sylvia: Die Erfindung der Humboldtschen Universität. Die Konstruktion der deutschen Universitätsidee in der ersten Hälfte des 20. Jahrhunderts. In: Historische Anthropologie 10 (2002). pp. 183-205.

29 Raxhon, Université de Liège (cf. note 15), p. 187.

30 Raxhon, Université de Liège (cf. note 15), p. 188.

31 Deneckere, Uit de ivoren toren (cf. note 9), p. 263.

32 Dor, Juliette et al.: Où sont les femmes? La féministation à l'Université de Liège. Liège 2017. 
students, researchers, professors and administrators, based on archival documents and an impressive series of interviews, the authors discuss the position and experiences of women at the University of Liège, from the acceptance of the first female student in 1881 up to today.

How will the Catholic University of Leuven commemorate its arrears with regard to the admission of female students, which took place almost half a century later than at the other Belgian universities, on the occasion of its upcoming $600^{\text {th }}$ anniversary in 2025? For obvious reasons, female students and scholars were not a topic at the small workshop that was organised in October 2017 to celebrate the bicentenary of the state university that had existed in Leuven between 1817 and 1835. It is commendable that this small anniversary was not (entirely) forgotten. But the fact that the collective volume has only been published in the spring of $2021,^{33}$ might indicate where current priorities lie.

Also because of the focus of the workshop's presentations on the common history of the three state universities and on the different jubilee traditions in Leuven, Ghent and Liège, the publication presents a notable deflection from the other jubilee books' narrative. As confirmed by Jo Tollebeek and Tom Verschaffel in their chapter in the volume, the 2017 workshop as a more humble celebration fits nicely into the tactics of self-representation as they were developed at the University of Leuven. ${ }^{34}$ The anniversary of the Catholic university, founded in 1834, was celebrated in 1859, 1884 and 1909. From 1925 onwards, though, the foundation of the old, medieval university, founded in 1425 by Pope Martin V, was commemorated. The fact that the French revolutionaries had abolished the university of Leuven in 1797, and that between 1817 and 1835 the buildings were occupied by a state university was gradually 'forgotten'. Continuity and tradition are generally identified with quality, and the KULeuven is certainly no exception to this rule. ${ }^{35}$ From the same reasoning, Raxhon and Granata even dare to claim that "the University of Liège is together with the University of Ghent the oldest university of Belgium" ${ }^{36}$ Strictly speaking this is correct, because the currently existing university in Leuven only dates from 1834. It is highly probable,

33 Meirlaen, Matthias et al. (eds.): Een wereld van verschil? De universiteit in het Zuiden tijdens het Verenigd Koninkrijk der Nederlanden vanaf 1817. Brussels 2021 (Koninklijke Vlaamse Academie van België voor Wetenschappen en Kunsten 36).

34 Tollebeek, Jo and Tom Verschaffel: Over weerbaarheid en prestige. De jubileumvieringen van de Leuvense universiteit sinds 1834. In: Meirlaen et al., Een wereld van verschil? (cf. note 33), pp. $193-214$.

35 Vandeweyer, Machteld: Leuven loven. De zelfperceptie van de Leuvense universiteit tussen 1884 en 2016. Unpublished master dissertation. Leuven 2019.

36 Raxhon, Université de Liège (cf. note 15), p. 139. 
though, that in 2025 the public relations department at the KULeuven will completely ignore such a statement.

\section{Getting the Message Through in Different Ways}

The only reason to include this statement, which is somewhat confusing for the general public, for whom the Liège jubilee book is intended, is to use it as a quality label. Nevertheless, in most of the recent jubilee publications appears to be enough room for a critical approach. Deneckere does not shy away from such an approach to elaborate on the stormy rector elections that shook up Ghent University precisely in its anniversary year, and that were widely spread in the national press too. The media clearly liked the feuds and intrigues that seemed to indicate that the ancient tensions between Catholics and Freemasons still live on in the former state university, which had made pluralism its trademark since the 1960s. In her epilogue, Deneckere also formulates rather harshly, that there was a fundamental contradiction in the two hundred years history of Ghent University between being "capable of great things, but equally able to counteract that greatness on all levels". ${ }^{37}$

During the past decades, the opportunities for a critical and precise historical work on the universities' past have gradually increased, at least partly in consequence of the greater importance of the third and fourth element in jubilee celebrations, namely cultural activities open to the general public or, to put it negatively, due to the reduced importance that university authorities attach to historical publications in the jubilee context. Even from a budgetary perspective are the massive range of activities offered to the wider public nowadays far more crucial and can hardly be separated from the fields of marketing and propaganda. Of course, this kind of cultural events on the occasion of the jubilee have always been crucial for the university's propaganda, yet their scope has been extended drastically. Closely related to this have also the media that were mobilised to design and convey the celebrations, and the addressed or recruited publics changed fundamentally. ${ }^{38}$ The partying company is no longer limited to 'masters' and students, but attempts are made to reach out to alumnae, city in-

37 Deneckere, Uit de ivoren toren (cf. note 9), p. 328.

38 Ash, Mitchell G.: Die Universitätsgeschichtsschreibung an der Universität Wien im Jubiläumsjahr 2015 - zwischen historischer Reflexion und Eventkultur. In: Universitätsgeschichte schreiben. Inhalte - Methoden - Fallbeispiele. Ed. by Livia Prüll, Christian George and Frank Hüther. Mainz 2019 (Beiträge zur Geschichte der Universität Mainz Neue Folge 14). pp. 221239, p. 222. 
habitants and all kinds of sympathisers by making use of new and different means of communication.

A decisive instrument in order to realise this ambition in the Ghent context was UGentMemorie, a website launched already in 2010 and further developed ever since. ${ }^{39}$ Functioning as the virtual memory of the university, the platform was conceived by employees of the Institute for Public History and its common thread was and is "the interaction between university and city, science and society", according to the website authors. For the historian Liesbet Nys from KULeuven, one of the most valuable objectives of UGentMemorie is how it strives to involve the broad (university) community in the project. Not only does a great deal of student research, which otherwise might be immediately submerged, find its way to a wide audience via the platform. The broad public is also explicitly encouraged to participate: visitors to the website are fostered to add memories from their university life or to supplement biographical entries about the university's professors, based on their own experiences. ${ }^{40}$

In addition to this virtual exposition, a large number of exhibitions had been organised during the jubilee year 2017 in both cities. In Ghent, the major exhibition was displayed at the city museum. Under the title 'Stad en universiteit. Sinds 1817' [City and university. Since 1817] the exhibits not only promised to offer a retrospective into the topical interaction between city and university "over the past two hundred years", but also to examine "opportunities for the future", ${ }^{41}$ therefore perfectly in line with the university's general message on the occasion of the jubilee. The same applies to the situation in Liège where the primary exhibition was titled 'J'aurai 20 ans en 2030' [I will be 20 years old in 2030] and aimed to "open up debate, tickle curiosity and shed light on more than 50 essential questions for thinking about the future". ${ }^{42}$

Another attempt in Ghent to involve the larger public consisted in a campaign to reconstruct the university's life story on the basis of 200 objects. These objects were assembled among the university's core and broader context,

39 Het virtuele geheugen van de UGent. ugentmemorie.be (26.2.2021).

40 Nys, Liesbet: UGentMemorie: universiteitsgeschiedenis op digitale leest. In: Contemporanea 39:3 (2017). https://www.contemporanea.be/nl/article/2017-3-geschiedenis-online-nys (26.2. 2021); see also Danniau, Fien, Ruben Mantels and Christophe Verbruggen: Towards a Renewed University History: UGentMemorie and the Merits of Public History, Academic Heritage and Digital History in Commemorating the University. In: Studium 5:3 (2012). pp. 179-192 and Danniau, Fien: Public History in a Digital Context. Back to the Future or Back to Basics? In: BMGN - Low Countries Historical Review 128:4 (2013). pp. 118-144.

41 Stad en universiteit. Sinds 1817. stamgent.be/nl_be/evenementen/stad-en-universiteit-sinds1817 (26. 2. 2021).

42 Lecrenier, Philippe: J'aurai 20 ans en 2030. Question(s) d'avenir(s). Liège 2017. 
"in particular students, staff members of the university and the city of Ghent, alumnae, owners of student housing”, as well as "chip shop and pub owners, community police officers and Erasmus students". ${ }^{43}$ The Liège counterpart was the exhibition ' $\mathrm{Du}$ poil de mammouth à l'oeil du cyclope. 200 bizarreries scientifiques universitaires' [From mammoth hair to cyclops eye. 200 academic scientific quirks], organised at the initiative of various natural science museums and university departments. Giving an overview of the whole scope of activities in both cities would lead too far, ranging from a guided city walk over public debates to an international rowing regatta. However, from the perspective of university historians the website UGentMemorialis cannot be left unmentioned here. ${ }^{44}$ It functions as the contemporary version of an ancient academic tradition of presenting the professorial corps in memorial books.

In the run-up to the 2017 jubilee, the opening of a new university museum in Ghent had been discussed, but it materialised only in October 2020, as another lasting memory of the bicentenary. The Ghent University Museum (GUM) presents itself as a 'Forum for science, doubt \& art'. ${ }^{45}$ It wants to challenge people to look at science and society in a new way. "We do not show the end result of science, we show the way to it," says Marjan Doom, director of the GUM. ${ }^{46}$ The permanent exhibition works on seven themes: chaos, doubt, model, measurement, imagination, knowledge and network. Unlike most university museums, the focus is not on the history of the university or a discipline. Instead, GUM tries to bring together the entire Ghent academic heritage collection that represents a diversity of disciplines. The ambition is to emphasise the diversity and versatility of science by placing objects from different disciplines simply next to each other. The clash between these objects is used as a handle to represent the complex and often non-linear scientific process that precedes the results. So instead of trying to tell audiences what science is, the museum wants to encourage its public to enter into the minds of scholars, to explore science together and to stimulate the critical awareness of the visitors. ${ }^{47}$ This approach thus corresponds to the strong Ghent tradition in the field of philosophy of science.

43 De Rynck, Patrick et al.: 200 jaar UGent in 200 objecten. Lichtervelde 2017.

44 Universiteit Gent: UGentMemorialis. ugentmemorialis.be (26.2.2021).

45 Gents Universiteits Museum: Forum voor wetenschap, twijfel \& kunst. gum.gent (26.2.2021). 46 Anon.: Welkom in het hoofd van de wetenschapper. In: De Standaard (30.9.2020). pp. 1-7, p. 2.

47 See Doom, Marjan: The Museum of Doubt. A modest manifesto by a science curator. Ghent 2020. 


\section{Conclusion}

Another and more recent Ghent tradition is the focus on public history. Although the Institute for Public History dates back to 2007, it is not a coincidence that Ghent University was in 2016-2017 the first Belgian university to offer a programme in public history. Even if this launch was not a direct output of the university jubilee, it was at least largely indebted to the expertise built up in the run-up to the bicentenary. The programme consists of a cluster of courses including two internships which are coordinated by Fien Danniau who was one of the key drivers behind UGentMemorie and Gita Deneckere, among others. That the official jubilee publication is a book that really wants to be read and not only serves to decorate coffee tables and bookcases, can therefore also be seen as the result of a progressive public-historical insight, as it was claimed at the Institute's tenth anniversary. ${ }^{48}$ The ambition to make the past relevant for today and the inclusion of a clear master narrative with which one can identify as a reader are crucial public-historical characteristics of the book.

However, not only in Deneckere's book, but actually in most, if not all, of the above-mentioned initiatives, the two central messages of both celebrating universities - Ghent and Liège - are reflected: defending and protecting the university by emphasising its possible social relevance, and creating a larger (university) community by investing into the natural partnership between city and university. Is history used, or even misused in this way in order to convey a certain message? To a certain extent definitely yes. However, insinuating that any of the scholars or event organisers involved explicitly intend to press the past for answers to contemporary questions or seek for any kind of self-confirmation, is probably going a bit too far. Instead, these jubilee stakeholders want to be interrogated by perspectives from the past. And after all, particularly the authors of the jubilee publications actually only practice themselves what they call for at the level of the university: to give history a social relevance and to make their findings and insights available to the wider public. Isn't that what all of us as historians have to do today?

48 Cachet, Tamer: 10 jaar Instituut voor Publieksgeschiedenis. https://www.ipg.ugent.be/nl/ blog/10-jaar-instituut-voor-publieksgeschiedenis (2.5.2018). 